М. М. Корда, Г. Г. Шершун, М. І. Куліцька, П. Г. Лихацький

ДВНЗ “Тернопільський державний медичний університет

імені I. Я. Горбачевського МОЗ Украӥни”

\title{
ПРИНЦИПОВІ ПІДХОДИ ДО ВИКЛАДАННЯ БІОХІМІЇ У ТЕРНОПІЛЬСЬКОМУ ДЕРЖАВНОМУ МЕДИЧНОМУ УНІВЕРСИТЕТІ ІМЕНІ І. Я. ГОРБАЧЕВСЬКОГО 3 ОГЛЯДУ НА ВИМОГИ КОМПЕТЕНТНОСТІ
}

\author{
M. M. Korda, H. H. Shershun, M. I. Kulitska, P. H. Lykhatskyi \\ I. Horbachevsky Ternopil State Medical University

\begin{abstract}
KEY APPROACHES TO THE TEACHING OF BIOCHEMISTRY IN DETERMINED BY COMPETENCE REQUIREMENTS
\end{abstract} \\ I. HORBACHEVSKY TERNOPIL STATE MEDICAL UNIVERSITY AS
}

\begin{abstract}
Мета роботи - спроба аналізу викладання фундаментальних теоретичних дисциплін у медичному виші, зокрема з огляду на такий елемент, як компетентність. Компетентнісний підхід потребує посилення самостійної і продуктивної діяльності студентів, розвитку їх особистісних якостей і творчих здібностей, що є важливим інструментом модернізації медичної освіти.

Основна частина. Сучасний фахівець медицини повинен мати не лише грунтовні знання, певний багаж професійних навичок й умінь, але і здатність творчо застосовувати набуті знання у різних життєвих ситуаціях, гнучко та оперативно адаптуватися в сучасному динамічному суспільстві з його інформативними та інноваційними викликами, не втрачати доленосний орієнтир. Компетентнісна освітня політика і є таким орієнтиром на шляху до міжнародних стандартів освіти. Акцент на виховання компетентності майбутнього клініциста, на наше переконання, повинен бути пріоритетним вже на етапі вивчення базових теоретичних дисциплін, зокрема біологічної хімії як основи клініко-лабораторної діагностики.

Висновок. У професійному розвитку фахівця медицини провідним фактором є реалізація принципів компетентнісного підходу на етапі вивчення базових теоретичних дисциплін.
\end{abstract}

Ключові слова: біохімія; компетентність; знання; уміння; комунікація; відповідальність.

The aim of the work - to analyse teaching of fundamental disciplines in a medical school from the perspective of competency-based education. This approach requires strengthening of independent and productive learning by students, development of their personal potential and creative abilities. As a result, competency-based education is an important tool in the modernization of medical education.

The main body. A modern medical specialist must not only possess comprehensive knowledge and a certain level of professional skills, but also the ability to apply the acquired knowledge creatively in different real-life situations, to demonstrate alacrity in a contemporary dynamic society presenting information and innovation challenges, all while holding on to a set of moral guidelines. Competency-based education offers helpful signposts on the path to international standards of education. In our opinion, in medical education the emphasis on developing competencies should be placed even at the stage of studying basic theoretical disciplines, in particular, biological chemistry, which serves as a foundation of clinical and laboratory diagnostics.

Conclusion. Implementation of competency-based education can play a key role in the training of a health care professional, in particular at the stage of learning basic theoretical disciplines.

Key words: biochemistry; competency-based education; knowledge; skills; communication; responsibility.

Вступ. В Україні триває реформування освіти, основний акцент якої спрямований на якість підготовки професійних кадрів. Навчання повинно бути максимально наближеним до майбутньої сфери професійної діяльності, включаючи формування фахової і соціальної компетентності - організаторського та управлінського досвіду, культури особис-

() М. М. Корда, Г. Г. Шершун, М. І. Куліцька, П. Г. Лихацький тісного спілкування і дискусії в колективі, здатності адекватно і гнучко діяти в різних проблемних ситуаціях, творчо і відповідально застосовуючи здобуті знання й уміння.

Мета роботи - спроба поглибленого аналізу викладання фундаментальних теоретичних дисциплін, зокрема біохімії у закладі вищої медичної освіти, з огляду на такий елемент, як компетент- 
ність. Предметний компетентнісний підхід потребує посилення самостійної і продуктивної діяльності студентів, розвитку їх особистісних якостей і творчих здібностей, що $є$ важливим інструментом модернізації медичної освіти [2, 4].

Основна частина. Фундаментальною основою якісної характеристики фахівця медицини $є$ не лише набуття в процесі навчання студентів-медиків певного багажу теоретичних знань, загальної інформативності. Основою самореалізації є розвиток уміння робити узагальнення, логічні висновки, розвиток новітніх підходів до професійних навичок, мотивація до самоосвіти, гармонійного розвитку, набуття цілісного досвіду вирішення проблем теоретичного і практичного змісту, прагнення до досконалості. Це $є$ маркерами професійного і соціального компетентнісного становлення кожного молодого фахівця [2, 3]. Компетентнісний підхід передбачає зміщення акцентів з накопичення знань, умінь, навичок у процесі навчання до здатності практично діяти, творчо застосовувати здобуті знання, а також почуватися впевненим і успішним у соціальному середовищі [5].

Біохімічні підходи посідають чільне місце у діагностичному процесі, контролі за перебігом хвороби, ефективності лікування. Тому клініко-лабораторна ерудиція, компетентність особливо важливі в практиці лікаря $[1,5]$. Формування такої ерудиції започатковується вже на другому курсі при вивченні медичної біохімії. На прикладі викладення тем, максимально наближених до клінічної практики, ми прагнемо показати наше бачення способів формування у студента-медика предметно-фахової компетентності.
Керуючись цим принципом, ми розробляємо для кожної теми категорії предметної компетентності, відмічаючи у матриці ті, які є головними в їх засвоєнні, виконанні, комунікативному спілкуванні, відображають досягнення динамічної комбінації знань, умінь, практичних навичок, способів логічного мислення і $\epsilon$ результатом ефективності навчання на певному рівні ерудиції студентів. Це відображено в кожній методичній вказівці для студентів і викладачів.

Мінімальні вимоги до засвоєння теми - це знання, пояснення, 3'ясування, розуміння ключових категорій. Вищий рівень вимог - це уміння самостійно провести належні лабораторні дослідження, дотримуючись принципу і алгоритму методу, використовуючи час, уміння об'єктивно оцінити їх якість. Наступний етап - колективна клініко-лабораторна інтерпретація результатів, демонстрація ефективності спілкування в групі, спираючись на сукупність отриманих знань, уміння вирішувати тематичні тестові завдання, що в нашому розумінні $\epsilon$ вимогами комунікативної компетентності.

Автономія та ефективність, на наше переконання, - це навичка пошуку з різних джерел, обробки і аналізу інформації щодо конкретних питань теми, здатність у дискусії висловлювати нові ідеї, припущення, мотивації, свідомо приймати обгрунтовані рішення і нести за них відповідальність. Вважаємо це прерогативою останніх категорій компетентності. Тому, приміром, матриця компетентності до теми “Ліпопротеїни крові” має загальний вигляд (табл. 1).

За таким же принципом обгрунтовані матриці до кожної з тем практичного заняття, але акценти

Таблиця 1. Матриця компетентностей

\begin{tabular}{|l|c|c|c|c|}
\hline \multicolumn{1}{|c|}{ Категорії предметної компетентності } & Знання & Уміння & $\begin{array}{c}\text { Комуні- } \\
\text { кація }\end{array}$ & $\begin{array}{c}\text { Автономія та } \\
\text { відповідальність }\end{array}$ \\
\hline $\begin{array}{l}\text { Розуміння поняття “ліпопротеїни”: представники, місця їх } \\
\text { утворення, структуризація, функції, напрямки транспорту } \\
\text { в плазмі крові }\end{array}$ & + & & & \\
\hline Взаємоперетворення різних форм ліпопротеїнів у крові & + & & & \\
\hline $\begin{array}{l}\text { Обгрунтування понять “добрий” і “поганий” холестерин, з } \\
\text { якими транспортними формами вони асоціюються. Знання } \\
\text { механізмів утворення Лпнщ і ЛПВщ }\end{array}$ & + & + & + & \\
\hline $\begin{array}{l}\text { Осмислення наслідків для організму гіперхолестеринемії, по- } \\
\text { няття про генетичні захворювання, спричинені порушенням } \\
\text { метаболізму ліпопротеїнів }\end{array}$ & + & + & + & \\
\hline $\begin{array}{l}\text { Уміння провести дослідження співвідношення холестерино- } \\
\text { вих ліпопротеїнових фракцій, користуючись електрофорегра- } \\
\text { мами ліпопротеїнів, дати клініко-лабораторну інтерпретацію } \\
\text { результатів шляхом загальної дискусії }\end{array}$ & & + & + & + \\
\hline
\end{tabular}


щодо лабораторної роботи, обміну інформацією, дискусії, рольового спілкування (комунікативні принципи) зміщуються на біохімічні показники, що мають важливе значення в клініко-діагностичному процесі (діастаза, глюкоза в крові і сечі, білки крові, жовчні пігменти, кетонові тіла, ліпопротеїни, сечовина, трансамінази тощо). Матриці компетентності слугують студентам орієнтиром вимог, що забезпечують оптимальне засвоєння матеріалу теми.

Висновки. 1. У професійному розвитку провідним фактором є реалізація компетентнісного підходу.

\section{Список літератури}

1. Карпець М. В. Роль медичної хімії у формуванні студента-медика / М. В. Карпець // Медична освіта. 2014. - № 3. - С. 72-75.

2. Запорожан В. М. Інноваційні підходи до підготовки сучасного лікаря / В. М. Запорожан // Медична освіта. 2014. - № 2. - С. 38-40.

3. Глузман О. В. Базові компетентності: сутність та значення в життєвому успіху особистості / О. В. Глузман // Педагогіка і психологія. - 2009. - № 2. - С. 51-61.

\section{References}

1. Karpets, M.V. (2014). Rol medychnoi khimii u formuvanni studenta-medyka [The role of medical chemistry in the formation of a medical student]. Medychna osvita Medical Education, 3, 72-75 [in Ukrainian].

2. Zaporozhan, V.M. (2014). Innovatsiini pidkhody do pidhotovky suchasnoho likaria [Innovative approaches to the training of a modern physician]. Medychna osvita-Medical Education, 2, 38-40 [in Ukrainian].

3. Hluzman, O.V. (2009). Bazovi kompetentnosti: sutnist ta znachennia $\mathrm{v}$ zhyttievomu uspikhu osobystosti [Basic competencies: the essence and importance in the vital success of the individual]. Pedahohika i psykholohiia Pedagogy and Psychology, 2, 51-61 [in Ukrainian].

4. Luhovyi, V.I. (2009). Yevropeiska kontseptsiia kompetentnisnoho pidkhodu u vyshchii shkoli ta problemy
2. Компетентнісне професійне становлення медичного фахівця формується вже на етапі вивчення базових теоретичних дисциплін.

3. Компетентність фахівця дозволяє мобільно змінювати професійну діяльність за умов динамічного розвитку суспільства, втілення реформ професійної галузі.

4. Впровадження матриць компетентності в методичні вказівки для студентів є орієнтиром оптимального засвоєння матеріалу теми.

4. Луговий В. І. Європейська концепція компетентнісного підходу у вищій школі та проблеми ï реалізації в Україні / В. І. Луговий // Педагогіка і психологія. - 2009. № 2. - C. 13-26.

5. Компетентнісний підхід та формування ключових компетентностей в підготовці студентів вищих навчальних медичних закладів / М. М. Шінкарук-Диковицька, Г. М. Побережна, Т. В. Федик, Л. О. Ковальчук // Вісник Вінницького національного медичного університету. 2017. - T. 21, № 1(2). - С. 319-323.

yii realizatsii $v$ Ukraini [The European concept of competence approach in higher school and problems of its implementation in Ukraine]. Pedahohika i psykholohiia Pedagogy and Psychology, 2, 13-26 [in Ukrainian].

5. Shinkaruk-Dykovytska, M.M., Poberezhna, H.M., Fedyk, T.V., \& Kovalchuk, L.O. (2017). Kompetentnisnyi pidkhid ta formuvannia kliuchovykh kompetentnostei v pidhotovtsi studentiv vyshchykh navchalnykh medychnykh zakladiv [Competent approach and formation of key competencies in the training of students of higher educational institutions]. Visnyk Vinnytskoho natsionalnoho medychnoho universytetu Bulletin of the Vinnytsia National Medical University, 21, 1 (2), 319-323 [in Ukrainian]. 